\title{
Performance Evaluation of RAP and WMA Mixtures Located in MN/Road Test Cells through Air Voids Analyses $\mathrm{MN} / \operatorname{Road}$ 시험포장 구간내의 공기량 측정 및 결과값 분석을 통한 $\mathrm{RAP}$ 및 저온 아스팔트(WMA) 혼합물의 특성 평가
}

\author{
\begin{tabular}{l|l} 
Ki Hoon Moon 문 기 훈 & Member · Senior Researcher (Ph.D.), Samsung Construction and Trading Corporation · Corresponding author
\end{tabular} \\ (E-mail : moonx113@umn.edu) \\ Augusto Cannone Falchetto \\ Jin Hoon Jeong 정 진 훈 $\quad$ Member·Associate Professor (Ph.D.) · Department of Civil Engineering, Inha University (E-mail : jhj@inha.ac.kr)
}

\begin{abstract}
PURPOSES : This research is to evaluate the mechanical performance of different types of Hot Mix Asphalt (HMA) pavement cells prepared for $\mathrm{MN} /$ Road field testing section through an extensive experimental analysis of air voids and simple statistical evaluation tools (i.e. hypothesis test).

METHODS : An extensive experimental work was performed to measure air voids in 82 asphalt mixture cores (238 samples in total) obtained from nine different types of road cell located in MN/Road testing field. In order to numerically and quantitatively address the differences in air voids among the different test Cells built in MN/Road, a simple statistical test method (i.e. t-test) with 5\% significance was used.
\end{abstract}

RESULTS : Similar trends in air voids content were found among the mixtures including conventional HMA, Reclaimed Asphalt Pavement (RAP) and Warm Mix Asphalt (WMA) combined with taconite aggregate this provides support to the use of RAP and WMA technology in the constructions of asphalt pavement. However, in case of acid modified HMA mixtures, significant differences in air void content were observed between on the wheel path and between wheel path location, which implies negative performances in rutting and thermal cracking resistances.

Conclusions : It can be concluded that use of RAP and WMA technology in the construction of conventional asphalt pavement and the use of PPA (Poly Phosphoric Acid) in combinations with SBS (Styrene Butadiene Styrene) in asphalt binder production provide satisfactory performance and, therefore, are highly recommended

\section{Keywords}

air voids, MN/Road testing cell, hot mix asphalt (HMA), reclaimed asphalt pavement (RAP), warm mix asphalt (WMA), taconite aggregate, rutting

Corresponding Author : Ki Hoon, Moon, Senior Researcher Samsung Construction and Trading Corporation, 5th Floor, Daeryung Gangnam Tower 826-20, Yeoksam1-Dong, Gangnam-Gu, Seoul, 135-935, Korea

Tel : +82.2.2145.6507 Fax : +82.2.2145.6500

E-mail : moonx113@umn.edu
International Journal of Highway Engineering

http://www.ksre.or.kr/

ISSN 1738-7159 (print)

ISSN 2287-3678 (Online)

Received May. 22. 2014 Revised May. 22. 2014 Accepted Jul. 25. 2014

\section{INTRODUCTION}

In asphalt pavement materials characterization and research areas, laboratory measured properties are expected to give an indication of the pavement field performance. Depending on temperature, these 
properties affect the different performances of asphalt binder and corresponding mixtures (Hot Mix Asphalt - HMA). For instance, top-down or bottom-up cracks occur when thermal stress exceeds the strength in the asphalt pavement; these phenomena are considered as major distress, especially at low temperatures. Thermal stress, critical cracking temperature, creep and relaxation properties of asphalt binder and mixtures can be evaluated through two test methods: Bending Beam Rheometer (BBR) and Indirect Tensile (IDT) creep tests, which are currently specified in AASHTO standards (AASHTO T313-06, 2006; AASHTO T322-03, 2006) and in a recent research by Marasteanu O. M. and co-workers (Marasteanu et al., 2009). At high temperatures, rutting is identified as the dominant distress of asphalt pavement; complex modulus, $G^{*}$, and phase angle, $\delta$, are the parameter used for high temperature material characterization. According to AASHTO and ASTM standards, three types of mechanical tests exist to obtain $G^{*}$ and $\delta$ : Dynamic Shear Rheometer (DSR), Dynamic Modulus (DM) and Cubic Beam tests (AASHTO T313-05, 2006; AASHTO T342-11, 2011; ASTM D7552-09, 2009).

Asphalt pavement performance is also strongly affected by air voids, which directly determines the asphalt material performances both at low and high temperatures. Very low air voids (e.g. less than $2 \%$ ) can induce flushing, bleeding and loss of stability in asphalt pavement, when associated to the rearrangement of aggregate particles due to the compacting effect of traffic load. Such phenomena can lead into reduced skid resistance and increased rutting on the pavement surface. On the other hand, high air voids content results in an increase of permeability which may significantly affect the durability of the pavement due to freeze-thaw cycles and low temperature cracking. In order to limit these detrimental phenomena, many federal highway agencies recommend $4 \%$ as the optimum air void content in asphalt pavement (Buncher and Rosenberg, 2012). Nevertheless, not many studies were performed to investigated the change and distribution of air voids in real asphalt pavement structures (i.e. layers) by accounting of the different location on the pavement with respect to wheel load (e.g. between pass and drive way, between on the wheel path and between wheel path).

\section{LITERATURE REVIEW}

Several studies investigated the effect of air void on the mechanical performance of asphalt pavement. Some of the most relevant to the present study are briefly summarized thereafter. Barksdale and Miller (1977) evaluated fatigue and rutting characteristics of asphalt pavement considering various mixture variables. It was found that the fatigue life of asphalt mixtures significantly depends on the air voids and on asphalt binder content. They determined that for air voids in the range $2 \%$ and $4 \%$ 5\%, higher fatigue resistance can be achieved. In case of rutting, the moderate changes in mixture variables did not show a significant difference in the material response.

Brown and Cross (1992) investigated the effect of air voids on rutting characteristics of Hot Mix Asphalt (HMA). It was found that most of rutting occurred in the top 3 4 inches of the HMA pavement layer and air voids content higher than $3 \%$ was recommended for preventing premature rutting during the pavement service life. A remarkable correlation between angularity of aggregate and numbers of rutting events was also observed for asphalt pavement with air void content higher than $2.5 \%$. The authors concluded that rutting distress on high volume roadways can be mitigated if asphalt mixture is prepared with $3 \%$ air voids and using angular shaped aggregates.

Oliver and Alderson (1995) observed the effect of air void content on various mechanical properties of asphalt mixtures: resilient modulus, dynamic creep and wheel tracking results. Increase of resilient modulus was observed with decrease in air void content; modulus increased from $4.5 \mathrm{GPa}$ to $6.0 \mathrm{GPa}$ for air voids ranging from $1 \%$ to $7 \%$. Moreover, decrease in creep minimum slope (i.e. $m$-value) and in wheel tracking rate were observed with decrease of air voids indicating better deformation resistance.

Harvey and Wen Tsai (1996) evaluated fatigue life and flexural stiffness of various asphalt pavement mixtures prepared with different asphalt binders and air voids contents through laboratory-controlled strain flexural beam testing. Increase in predicted fatigue life and initial stiffness was observed with higher asphalt binder content and lower air voids percentage (e.g. level of 3 5\%), respectively.

Other advanced studies were performed to investigate and quantify air void volume fraction in whole asphalt mixture through Digital Image Processing (DIP) analysis. Masad et al. 
(2002) and Zelelew et al. (2008) captured and quantified air voids size (i.e. area) and distribution considering different factors, including compaction method and aggregate size, using X-Ray Computer Tomography (CT) technology. The air void distribution was characterized in terms of size and number of air voids in the captured image. In the case of the gyratory compaction method, a bath-tub shaped distribution of air voids was observed which means larger air voids concentration at the top and bottom surfaces of the specimen. Statistically significant difference in air voids distribution was observed for different compaction efforts (i.e. numbers), compaction methods and aggregate sizes. Nevertheless, no variation in air voids was observed for more than 150 gyrations.

In spite of a large number of studies focused on the effect of air voids on several mechanical properties of asphalt mixture, not many research efforts investigated the variations of air voids at different locations and depths in the layers of asphalt pavements prepared with asphalt mixtures having different mix design.

\section{RESEARCH OBJECTIVES}

In this paper the air voids contents calculated from various asphalt mixture cores prepared with different mix designs and including recycled materials (e.g. RAP), taconite aggregate and Warm Mix Asphalt (WMA) are evaluated and compared across the among the three mixture types HMA, RAP added asphalt mixtures and WMA. In order to achieve this objective, an extensive experimental works and statistical analyses were performed to measure air voids in asphalt mixture cores (82 cores and 238 samples in total) obtained from nine different types of MN/Road testing cell (MN/DOT, 2013).

\section{EXPERIMENTAL WORK}

\subsection{Preparations of Testing Specimens}

A total of 82 asphalt mixture cores extracted at nine different locations of testing cells in MN/Road were provided from Minnesota Department of Transportation (MN/DOT) to the asphalt pavement laboratory in University of Minnesota ( $\mathrm{U}$ of MN). Figures 1 and 2 show the schemes of MN/Road testing facility.

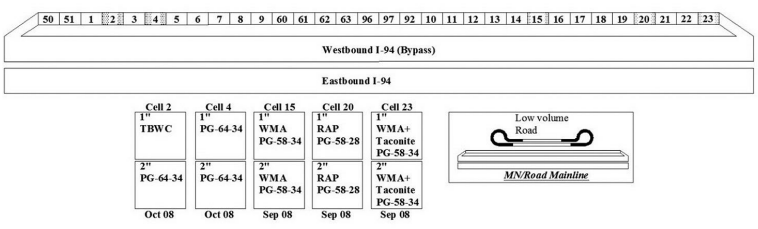

TBWC : Thin Board Wearing Courses

Fig. 1 Map of MN/Road Testing Cells

(Main road, Cells 2, 4, 15, 20 \& 23)

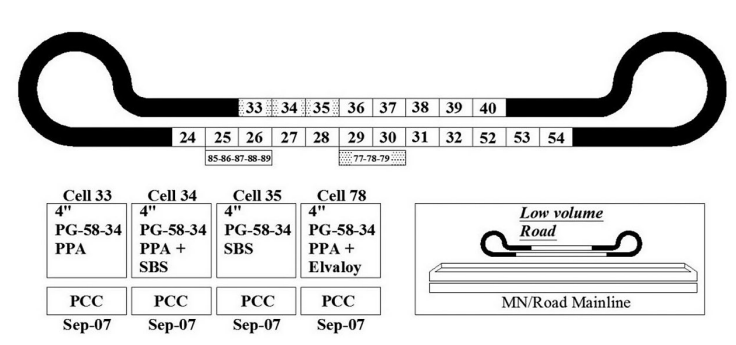

PPA: Poly-Phosphoric Acid, SBS: Styrene Butadiene Styrene

Fig. 2 Map of MN/Road Testing Cells

(Low volume road, Cells 33, 34, 35 \& 78)

Based on the thickness of the different layers included in each core, the asphalt mixture cylindrical samples were cut into 238 asphalt mixture specimens. Table 1 shows the mix design information of asphalt mixture cores extracted from MN/Road test cells.

Table 1. Mix Design of Prepared Asphalt Mixtures in This Study

\begin{tabular}{|c|c|c|c|}
\hline Cell & Binder PG & Description & $\mathrm{RAP}, \%$ \\
\hline 2 & PG64-34 & 12.5mm Dense Graded Super-pave & - \\
\hline 4 & PG64-34 & 12.5mm Dense Graded Super-pave & - \\
\hline 15 & PG 58-34 & $\begin{array}{c}\text { Warm Mix Asphalt (WMA) \& } \\
\text { 12.5mm Dense Graded Super-pave }\end{array}$ & - \\
\hline 20 & PG 58-28 & $\begin{array}{l}\text { Reclaimed Asphalt Pavement (RAP) \& } \\
\text { 12.5mm Dense Graded Super-pave }\end{array}$ & $30 \%$ \\
\hline 23 & PG 58-34 & $\begin{array}{c}\text { WMA \& Taconite aggregate \& } \\
\text { 12.5mm Dense Graded Super-pave }\end{array}$ & - \\
\hline 33 & PG 58-34 & $\begin{array}{l}0.75 \% \text { PPA + } 1.0 \% \text { Hydrated lime \& } \\
12.5 \mathrm{~mm} \text { Dense Graded Super-pave }\end{array}$ & - \\
\hline 34 & PG 58-34 & $\begin{array}{l}0.3 \% \text { PPA+1.0\% SBS+1.0\% Lime \& } \\
\text { 12.5mm Dense Graded Super-pave }\end{array}$ & - \\
\hline 35 & PG 58-34 & $\begin{array}{c}\text { 2.0\% SBS+1.0\% Lime \& } \\
\text { 12.5mm Dense Graded Super-pave }\end{array}$ & - \\
\hline 78 & PG 58-34 & $\begin{array}{l}\text { 0.3\% PPA+1.0\% SBS+1.0\% Elvaloy \& } \\
\text { 12.5mm Dense Graded Super-pave }\end{array}$ & - \\
\hline
\end{tabular}

The extracted cores presented different height (e.g. $4 \sim 7$ inches) and some of them include portions of Portland 
Cement Concrete (PCC) pavement layer. The samples were cored at different cell locations: drive way, pass way, on the wheel path and between wheel paths. Therefore, all the cores were divided based on a set of information including cell number, and core location. A total of two- to three-layer structure (top, intermediate and bottom) were considered to compute air voids. Asphalt mixture slices 1 inch thick $(2.54 \mathrm{~cm})$ were cut from the extracted core to perform air voids measurements. PCC layers were discarded from the analysis. All specimens were stored separately and air dried before testing (see Figures 3 and 4).
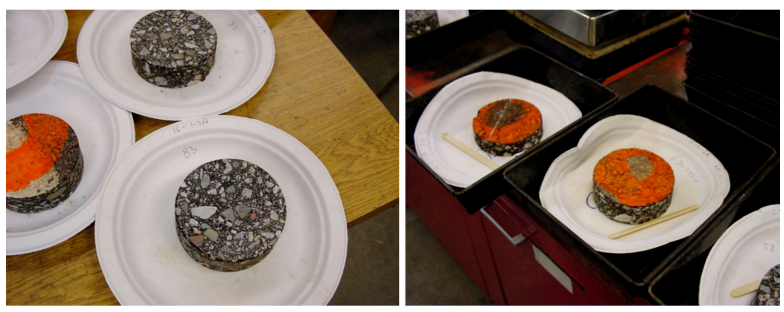

Fig. 3 Identifying Cores used in Air Voids Determination
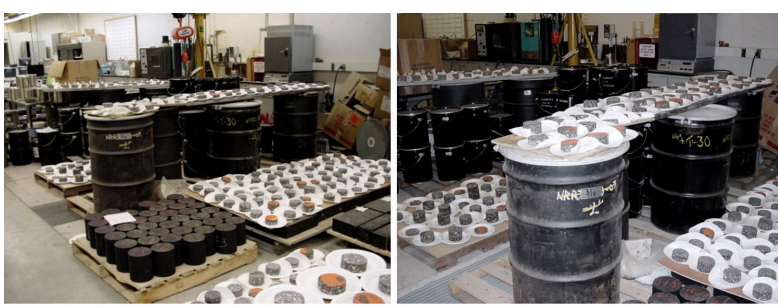

Fig. 4 Sorting Samples for Air Voids Determination

Details on the asphalt mixture specimens extracted from MN/Road testing cells are shown in Table 2.

Table 2. Asphalt Mixture Cores Identification Extracted from MN/Road Test Cells

\begin{tabular}{|c|c|c|c|c|c|c|c|c|}
\hline \multirow{2}{*}{ Cell } & \multirow{2}{*}{ Lift } & \multirow{2}{*}{ Thick. } & \multirow{2}{*}{ Des. } & \multicolumn{2}{|c|}{ Drive way (DW) } & \multicolumn{2}{|c|}{ Pass way (PW) } & \multirow{2}{*}{$\begin{array}{l}\text { Total } \\
\text { Specimens }\end{array}$} \\
\hline & & & & OWP & BWP & OWP & BWP & \\
\hline \multirow{2}{*}{2} & Botton & $2.54 \mathrm{~cm}$ & PG64-34 & 3 & 3 & 4 & 4 & 14 \\
\hline & Inter. & $2.54 \mathrm{~cm}$ & PG64-34 & 4 & 4 & 4 & 4 & 16 \\
\hline \multirow{3}{*}{4} & Botton & $2.54 \mathrm{~cm}$ & PG64-34 & 2 & 2 & 2 & 2 & 8 \\
\hline & Inter. & $2.54 \mathrm{~cm}$ & PG64-34 & 2 & 2 & 2 & 2 & 8 \\
\hline & Top & $2.54 \mathrm{~cm}$ & PG64-34 & 2 & 2 & 2 & 2 & 8 \\
\hline \multirow{2}{*}{15} & Inter. & $2.54 \mathrm{~cm}$ & WMA & 2 & 2 & 2 & 2 & 8 \\
\hline & Top & $2.54 \mathrm{~cm}$ & WMA & 2 & 2 & 2 & 2 & 8 \\
\hline \multirow{3}{*}{20} & Botton & $2.54 \mathrm{~cm}$ & RAP 30\% & 4 & 4 & 4 & 4 & 16 \\
\hline & Inter. & $2.54 \mathrm{~cm}$ & RAP 30\% & 4 & 4 & 4 & 4 & 16 \\
\hline & Top & $2.54 \mathrm{~cm}$ & RAP 30\% & 4 & 4 & 4 & 4 & 16 \\
\hline \multirow{3}{*}{23} & Botton & $2.54 \mathrm{~cm}$ & WMA\&T. & 2 & 2 & 2 & 2 & 8 \\
\hline & Inter. & $2.54 \mathrm{~cm}$ & WMA\&T. & 2 & 2 & 2 & 2 & 8 \\
\hline & Top & $2.54 \mathrm{~cm}$ & WMA\&T. & 2 & 2 & 2 & 2 & 8 \\
\hline
\end{tabular}

\begin{tabular}{c|c|c|c|c|c|c|c|c}
\hline \multirow{2}{*}{33} & Inter. & $2.54 \mathrm{~cm}$ & PG58-34 & 4 & 4 & 2 & 2 & 12 \\
\cline { 2 - 8 } & Top & $2.54 \mathrm{~cm}$ & PG58-34 & 4 & 4 & 2 & 2 & 12 \\
\hline \multirow{2}{*}{34} & Inter. & $2.54 \mathrm{~cm}$ & PG58-34 & 4 & 4 & 2 & 2 & 12 \\
\cline { 2 - 8 } & Top & $2.54 \mathrm{~cm}$ & PG58-34 & 4 & 4 & 2 & 2 & 12 \\
\hline \multirow{2}{*}{35} & Inter. & $2.54 \mathrm{~cm}$ & PG58-34 & 4 & 4 & 2 & 2 & 12 \\
\cline { 2 - 8 } & Top & $2.54 \mathrm{~cm}$ & PG58-34 & 4 & 4 & 2 & 2 & 12 \\
\hline \multirow{2}{*}{78} & Inter. & $2.54 \mathrm{~cm}$ & PG58-34 & 4 & 4 & 2 & 2 & 12 \\
\cline { 2 - 8 } & Top & $2.54 \mathrm{~cm}$ & PG58-34 & 4 & 4 & 2 & 2 & 12 \\
\hline \multicolumn{3}{c|}{ Summation } & 67 & 67 & 52 & 52 & 238 \\
\hline
\end{tabular}

\subsection{Air Void Determination from Asphalt Mixture Specimens}

Air voids were determined according to AASHTO T 16605 (2007) for each layer present in each core; an average was calculated if two (or more) replicates were available. The computed air voids in the different test cells locations and asphalt layers (drive way vs. pass way, on the wheel path vs. between wheel path, and among bottom, intermediate and top layers) were compared graphically and statistically. The following procedure was used to perform the air voids measurements:

- First, the separation plan between the different layers was highlighted for each core using a marker.

- An Excel table was prepared, and each layer of each core of each single cell received a unique identification number. That number was written on the correspondent core/layer. A paper plate was also labeled with the identification number and the sample's name (see Figure 3).

- The cores were then cut and each sample was placed on a separate paper plate and stored to dry before testing (see Figure 4).

- In this study two different types of method were used for calculation of specific gravity $\left(G_{m b}\right)$ :(AASHTO T 16605, 2007)

\section{Method A}

Bulk specific gravity: $G_{m b}$, was calculated as:

$$
G_{m b}=\frac{A}{B-C}
$$

Where:

$A:$ mass in grams of the specimen in air;

$B:$ mass in grams of the surface-dry specimen in air; 
$C:$ mass in grams of the specimen in water.

\section{Method B}

Method B was used for air voids calculation when a large amount of fine particles was observed on the surface of asphalt mixture core (or cut specimen). The specimen was placed in a large flat bottom pan of known mass (see Figure 3 and 4 ) and then kept in an oven at $110^{\circ} \mathrm{C}$ until it was possible to reduce the specimen in smaller particles (see Figure 5). The pan was placed back in the oven and dried to a constant mass. The pan and the specimen were cooled down to room temperature and then, dry mass, A,was calculated.Then bulk specific gravity $\left(G_{m b}\right)$ was obtained using the Equation (1).

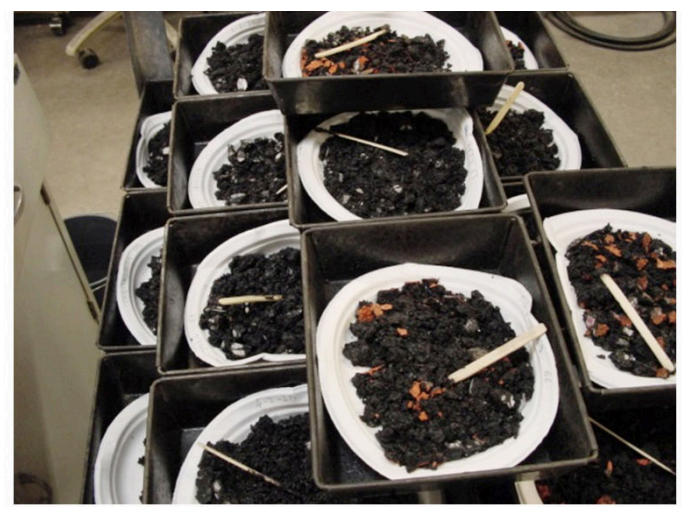

Fig. 5 Broken Down Asphalt Mixtures used for Air Voids Calculation

- Then the maximum specific gravity $\left(G_{m m}\right)$ values were calculated using the following equation:

$$
G_{m m}=\frac{A}{A+D-E}
$$

$A$ : mass oven dry sample in the air;

$D$ : mass of container filled with water $25^{\circ} \mathrm{C}$;

$E$ : mass of container filled with water and sample at $25^{\circ} \mathrm{C}$.

The values of $G_{m m}$ were calculated and provided by the Minnesota Department of Transportation (MN/DOT).

- Finally the values of air voids for each cell/core/layer were calculated using the results of Equations (1) and (2) as:

$$
\operatorname{Air} \operatorname{voids}(\%)=1-\frac{G_{m b}}{G_{m m}}
$$

After the following computation procedure, the computed results of air void were compared graphically and statistically as detailed in the next section.

\section{DATA ANALYSIS}

\subsection{Visual and Graphical Comparison}

The air void results obtained from performing the aforementioned test methods are listed in Tables 3 to 5, while Plots of the computed values of air voids are shown in Figures 6 to 8. Note that the following identification was used for layers within the same core:

Table 3. Results of $G_{m m}, G_{m b}$ and Air Voids

\begin{tabular}{|c|c|c|c|c|c|c|c|c|c|}
\hline Cell & Lift & Thick. & Des. & \multicolumn{3}{|c|}{ Location } & $\mathrm{Gmm}^{\mathrm{a}}$ & $\mathrm{Gmb}^{\mathrm{a}}$ & $\mathrm{A}, \vee^{\mathrm{a}}$ \\
\hline \multirow{8}{*}{2} & Bottom & $2.54 \mathrm{~cm}$ & PG64-34 & $D$ & 0 & $B$ & 2.439 & 2.285 & 6.30 \\
\hline & Inter. & $2.54 \mathrm{~cm}$ & PG64-34 & $D$ & 0 & 1 & 2.496 & 2.359 & 5.47 \\
\hline & Bottom & $2.54 \mathrm{~cm}$ & PG64-34 & $D$ & $B$ & $B$ & 2.439 & 2.253 & 7.53 \\
\hline & Inter. & $2.54 \mathrm{~cm}$ & PG64-34 & $D$ & B & I & 2.496 & 2.364 & 5.26 \\
\hline & Bottom & $2.54 \mathrm{~cm}$ & PG64-34 & $P$ & 0 & B & 2.439 & 2.267 & 7.04 \\
\hline & Inter. & $2.54 \mathrm{~cm}$ & PG64-34 & $P$ & 0 & I & 2.496 & 2.399 & 3.87 \\
\hline & Bottom & $2.54 \mathrm{~cm}$ & PG64-34 & $P$ & $B$ & $B$ & 2.439 & 2.271 & 6.87 \\
\hline & Inter. & $2.54 \mathrm{~cm}$ & PG64-34 & $P$ & $B$ & 1 & 2.496 & 2.337 & 6.34 \\
\hline \multirow{12}{*}{4} & Bottom & $2.54 \mathrm{~cm}$ & PG64-34 & $D$ & 0 & $B$ & 2.489 & 2.378 & 4.46 \\
\hline & Inter. & $2.54 \mathrm{~cm}$ & PG64-34 & $\mathrm{D}$ & 0 & 1 & 2.496 & 2.353 & 5.73 \\
\hline & Top & $2.54 \mathrm{~cm}$ & PG64-34 & $D$ & 0 & $\mathrm{~T}$ & 2.496 & 2.334 & 6.47 \\
\hline & Bottom & $2.54 \mathrm{~cm}$ & PG64-34 & $D$ & $B$ & $B$ & 2.489 & 2.388 & 4.04 \\
\hline & Inter. & $2.54 \mathrm{~cm}$ & PG64-34 & $\mathrm{D}$ & $B$ & 1 & 2.496 & 2.326 & 6.79 \\
\hline & Top & $2.54 \mathrm{~cm}$ & PG64-34 & $D$ & $B$ & $T$ & 2.496 & 2.345 & 6.05 \\
\hline & Bottom & $2.54 \mathrm{~cm}$ & PG64-34 & $P$ & $\mathrm{O}$ & $B$ & 2.489 & 2.388 & 4.04 \\
\hline & Inter. & $2.54 \mathrm{~cm}$ & PG64-34 & $P$ & 0 & 1 & 2.496 & 2.374 & 4.89 \\
\hline & Top & $2.54 \mathrm{~cm}$ & PG64-34 & $P$ & 0 & $\mathrm{~T}$ & 2.496 & 2.348 & 5.91 \\
\hline & Bottom & $2.54 \mathrm{~cm}$ & PG64-34 & $P$ & B & B & 2.489 & 2.387 & 4.10 \\
\hline & Inter. & $2.54 \mathrm{~cm}$ & PG64-34 & $P$ & B & I & 2.496 & 2.374 & 4.89 \\
\hline & Top & $2.54 \mathrm{~cm}$ & PG64-34 & $P$ & B & $\mathrm{T}$ & 2.496 & 2.315 & 7.35 \\
\hline \multirow{8}{*}{78} & Inter. & $2.54 \mathrm{~cm}$ & PG58-34 & I & 0 & I & 2.484 & 2.365 & 4.79 \\
\hline & Top & $2.54 \mathrm{~cm}$ & PG58-34 & I & 0 & $\mathrm{~T}$ & 2.484 & 2.384 & 4.02 \\
\hline & Inter. & $2.54 \mathrm{~cm}$ & PG58-34 & I & $B$ & I & 2.484 & 2.323 & 6.48 \\
\hline & Top & $2.54 \mathrm{~cm}$ & PG58-34 & I & $B$ & $\mathrm{~T}$ & 2.484 & 2.368 & 4.67 \\
\hline & Inter. & $2.54 \mathrm{~cm}$ & PG58-34 & $\mathrm{O}$ & 0 & 1 & 2.484 & 2.303 & 7.31 \\
\hline & Top & $2.54 \mathrm{~cm}$ & PG58-34 & $\mathrm{O}$ & 0 & $\mathrm{~T}$ & 2.484 & 2.329 & 6.26 \\
\hline & Inter. & $2.54 \mathrm{~cm}$ & PG58-34 & 0 & B & I & 2.484 & 2.259 & 9.06 \\
\hline & Top & $2.54 \mathrm{~cm}$ & PG58-34 & 0 & $B$ & $\mathrm{~T}$ & 2.484 & 2.285 & 8.01 \\
\hline \multicolumn{10}{|c|}{$\begin{array}{l}1^{\text {st }} \text { Row : D: Drive way, P: Pass way, I: Inside lane(for cell } 78 \text { only), O: Outside } \\
\text { lane(for cell } 78 \text { only) }\end{array}$} \\
\hline \multicolumn{10}{|c|}{$2^{\text {nd }}$ Row : O: On the wheel path, B: Between the wheel path } \\
\hline \multicolumn{10}{|c|}{$3^{\text {rd }}$ Row : T: top lift, l: intermediate lift, B: bottom lift } \\
\hline
\end{tabular}
(Cell 2, 4, 78 : Full depth reclamation) 
Table 4. Results of $G_{m m}, G_{m b}$ and Air Voids (Cell 15, 20, 23 : WMA and RAP mixtures)

\begin{tabular}{|c|c|c|c|c|c|c|c|c|c|}
\hline Cell & Lift & Thick. & Des. & \multicolumn{3}{|c|}{ Location } & $\mathrm{Gmm}^{\mathrm{a}}$ & $\mathrm{Gmb}^{\mathrm{a}}$ & $\begin{array}{l}\mathrm{A}_{\mathrm{V} V}^{\mathrm{a}}{ }^{\mathrm{a}}\end{array}$ \\
\hline \multirow{8}{*}{15} & Inter. & $2.54 \mathrm{~cm}$ & WMA & $D$ & 0 & t & 2.509 & 2.365 & 5.74 \\
\hline & Top & $2.54 \mathrm{~cm}$ & WMA & D & 0 & 1 & 2.509 & 2.404 & 4.18 \\
\hline & Inter. & $2.54 \mathrm{~cm}$ & WMA & D & B & I & 2.509 & 2.333 & 7.01 \\
\hline & Top & $2.54 \mathrm{~cm}$ & WMA & D & B & T & 2.509 & 2.291 & 8.67 \\
\hline & Inter. & $2.54 \mathrm{~cm}$ & WMA & $P$ & 0 & 1 & 2.509 & 2.327 & 7.25 \\
\hline & Top & $2.54 \mathrm{~cm}$ & WMA & $P$ & 0 & T & 2.509 & 2.357 & 6.06 \\
\hline & Inter. & $2.54 \mathrm{~cm}$ & WMA & $P$ & $B$ & 1 & 2.509 & 2.319 & 7.55 \\
\hline & Top & $2.54 \mathrm{~cm}$ & WMA & $P$ & B & T & 2.509 & 2.354 & 6.18 \\
\hline \multirow{12}{*}{20} & Bottom & $2.54 \mathrm{~cm}$ & PG58-28 & $D$ & 0 & B & 2.476 & 2.329 & 5.92 \\
\hline & Inter. & $2.54 \mathrm{~cm}$ & PG58-28 & $D$ & 0 & I & 2.527 & 2.380 & 5.82 \\
\hline & Top & $2.54 \mathrm{~cm}$ & PG58-28 & D & 0 & T & 2.527 & 2.376 & 5.95 \\
\hline & Bottom & $2.54 \mathrm{~cm}$ & PG58-28 & D & $B$ & B & 2.476 & 2.359 & 4.70 \\
\hline & Inter. & $2.54 \mathrm{~cm}$ & PG58-28 & D & $B$ & I & 2.527 & 2,359 & 6.65 \\
\hline & Top & $2.54 \mathrm{~cm}$ & PG58-28 & D & B & T & 2.527 & 2.353 & 6.88 \\
\hline & Bottom & $2.54 \mathrm{~cm}$ & PG58-28 & $P$ & 0 & B & 2.476 & 2.355 & 4.89 \\
\hline & Inter. & $2.54 \mathrm{~cm}$ & PG58-28 & $P$ & 0 & I & 2.527 & 2.409 & 4.66 \\
\hline & Top & $2.54 \mathrm{~cm}$ & PG58-28 & $P$ & 0 & $\mathrm{~T}$ & 2.527 & 2.354 & 6.84 \\
\hline & Bottom & $2.54 \mathrm{~cm}$ & PG58-28 & $P$ & $B$ & B & 2.476 & 2.371 & 4.26 \\
\hline & Inter. & $2.54 \mathrm{~cm}$ & PG58-28 & $P$ & $B$ & $\mid$ & 2.527 & 2.389 & 5.45 \\
\hline & Top & $2.54 \mathrm{~cm}$ & PG58-28 & $P$ & B & T & 2.527 & 2.353 & 6.87 \\
\hline \multirow[t]{12}{*}{23} & Bottom & $2.54 \mathrm{~cm}$ & WMA\&T. & $D$ & 0 & B & 2.483 & 2.361 & 4.93 \\
\hline & Inter. & $2.54 \mathrm{~cm}$ & WMA\&T. & D & 0 & I & 2.509 & 2.345 & 6.54 \\
\hline & Top & $2.54 \mathrm{~cm}$ & WMA\&T. & $D$ & 0 & $\mathrm{~T}$ & 2.509 & 2.378 & 5.22 \\
\hline & Bottom & $2.54 \mathrm{~cm}$ & WMA\&T. & $D$ & B & B & 2.483 & 2.361 & 4.93 \\
\hline & Inter. & $2.54 \mathrm{~cm}$ & WMA\&T. & $D$ & $B$ & I & 2.509 & 2.312 & 7.59 \\
\hline & Top & $2.54 \mathrm{~cm}$ & WMA\&T. & D & B & T & 2.509 & 2.321 & 7.51 \\
\hline & Bottom & $2.54 \mathrm{~cm}$ & WMA\&T. & $P$ & 0 & B & 2.483 & 2.385 & 3.95 \\
\hline & Inter. & $2.54 \mathrm{~cm}$ & WMA\&T. & $P$ & 0 & I & 2.509 & 2.323 & 7.41 \\
\hline & Top & $2.54 \mathrm{~cm}$ & WMA\&T. & $P$ & 0 & T & 2.509 & 2.316 & 7.71 \\
\hline & Bottom & $2.54 \mathrm{~cm}$ & WMA\&T. & $P$ & B & B & 2.483 & 2.410 & 2.94 \\
\hline & Inter. & $2.54 \mathrm{~cm}$ & WMA\&T. & $P$ & B & I & 2.509 & 2.351 & 6.30 \\
\hline & Top & $2.54 \mathrm{~cm}$ & WMA\&T. & $P$ & B & & 2.509 & 2.359 & 5.98 \\
\hline
\end{tabular}

Table 5. Results of $G_{m m}, G_{m b}$ and Air Voids

(Cell 33, 34, 35 : Acid modified HMA mixtures)

\begin{tabular}{|c|c|c|c|c|c|c|c|c|c|}
\hline Cell & Lift & Thick. & Des. & \multicolumn{3}{|c|}{ Location } & $\mathrm{Gmm}^{\mathrm{a}}$ & Gmba & $\begin{array}{c}A, V^{a} \\
{[\%]}\end{array}$ \\
\hline \multirow{8}{*}{33} & Inter. & $2.54 \mathrm{~cm}$ & PG58-34 & D & 0 & M & 2.478 & 2.387 & 3.66 \\
\hline & Top & $2.54 \mathrm{~cm}$ & PG58-34 & D & 0 & T & 2.478 & 2.376 & 4.13 \\
\hline & Inter. & $2.54 \mathrm{~cm}$ & PG58-34 & D & $B$ & M & 2.478 & 2.354 & 5.00 \\
\hline & Top & $2.54 \mathrm{~cm}$ & PG58-34 & D & B & T & 2.478 & 2.333 & 5.84 \\
\hline & Inter. & $2.54 \mathrm{~cm}$ & PG58-34 & P & 0 & M & 2.478 & 2.408 & 2.82 \\
\hline & Top & $2.54 \mathrm{~cm}$ & PG58-34 & $P$ & 0 & T & 2.478 & 2.339 & 5.63 \\
\hline & Inter. & $2.54 \mathrm{~cm}$ & PG58-34 & P & $B$ & M & 2.478 & 2.354 & 5.00 \\
\hline & Тор & $2.54 \mathrm{~cm}$ & PG58-34 & P & B & | & 2.478 & 2.294 & 7.45 \\
\hline & Inter. & $2.54 \mathrm{~cm}$ & PG58-34 & D & 0 & M & 2.474 & 2.350 & 5.01 \\
\hline & Top & $2.54 \mathrm{~cm}$ & PG58-34 & D & 0 & $\mathrm{~T}$ & 2.474 & 2.368 & 4.29 \\
\hline & Inter. & $2.54 \mathrm{~cm}$ & PG58-34 & D & B & M & 2.474 & 2.317 & 6.35 \\
\hline & Тор & $2.54 \mathrm{~cm}$ & PG58-34 & D & B & $\mathrm{T}$ & 2.474 & 2.330 & 5.82 \\
\hline
\end{tabular}

\begin{tabular}{|c|c|c|c|c|c|c|c|c|c|}
\hline & Inter. & $2.54 \mathrm{~cm}$ & PG58-34 & P & 0 & M & 2.474 & 2.371 & 4.16 \\
\hline & Top & $2.54 \mathrm{~cm}$ & PG58-34 & P & 0 & $\mathrm{~T}$ & 2.474 & 2.374 & 4.06 \\
\hline & Inter. & $2.54 \mathrm{~cm}$ & PG58-34 & $P$ & $B$ & M & 2.474 & 2.332 & 5.74 \\
\hline & Top & $2.54 \mathrm{~cm}$ & PG58-34 & $P$ & B & T & 2.474 & 2.305 & 6.83 \\
\hline & Inter. & $2.54 \mathrm{~cm}$ & PG58-34 & D & 0 & M & 2.471 & 2.343 & 5.19 \\
\hline & Top & $2.54 \mathrm{~cm}$ & PG58-34 & D & O & T & 2.471 & 2.335 & 5.49 \\
\hline & Inter. & $2.54 \mathrm{~cm}$ & PG58-34 & D & B & $M$ & 2.471 & 2.330 & 5.70 \\
\hline & Top & $2.54 \mathrm{~cm}$ & PG58-34 & D & B & $T$ & 2.471 & 2.290 & 7.35 \\
\hline & Inter. & $2.54 \mathrm{~cm}$ & PG58-34 & $P$ & 0 & M & 2.471 & 2.356 & 4.67 \\
\hline & Top & $2.54 \mathrm{~cm}$ & PG58-34 & $P$ & O & $T$ & 2.471 & 2.333 & 5.61 \\
\hline & Inter. & $2.54 \mathrm{~cm}$ & PG58-34 & $P$ & B & M & 2.471 & 2.338 & 5.40 \\
\hline & Top & $2.54 \mathrm{~cm}$ & PG58-34 & P & B & $\mathrm{T}$ & 2.471 & 2.301 & 6.88 \\
\hline
\end{tabular}

Plots of the computed values of air void using Method A and $\mathrm{B}$ are shown in Figures 6 to 8.

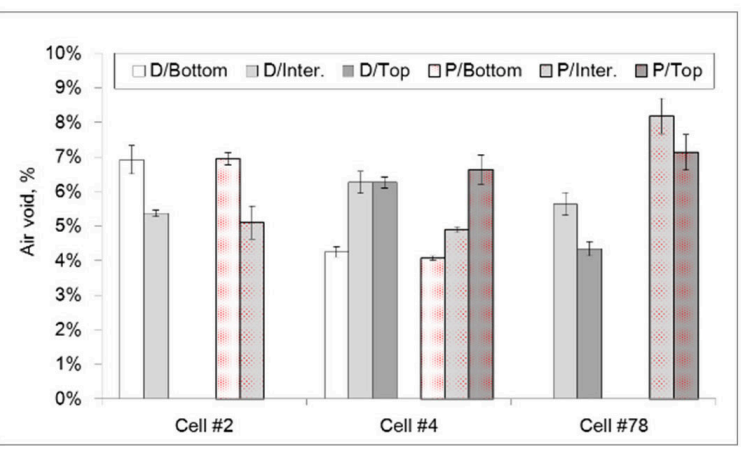

(a) Drive way vs. Pass way

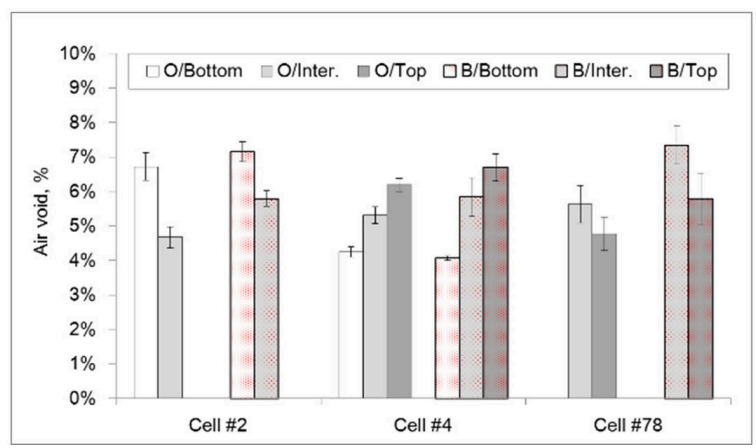

(b) On the wheel path vs. Between wheel path

Fig. 6 Air voids Comparisons among Cell \#2, 4 and 78

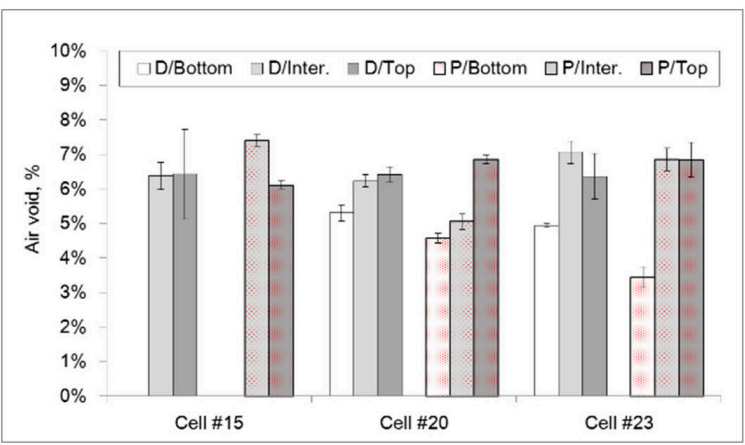

(a) Drive way vs. Pass way 


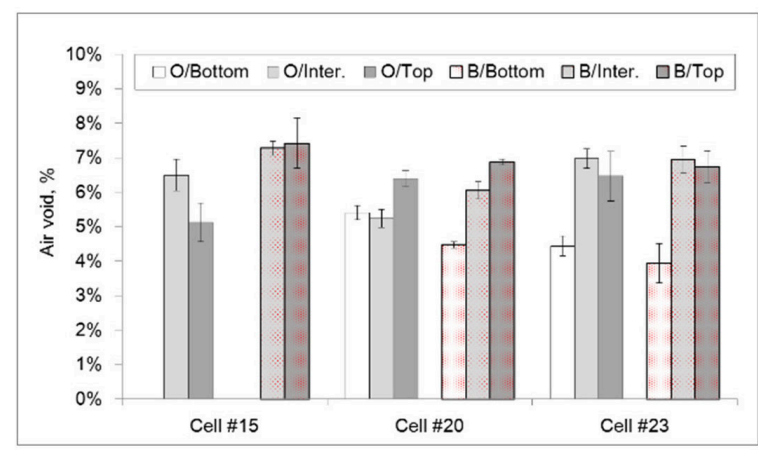

(b) On the wheel path vs. Between wheel path

Fig. 7 Air voids Comparisons among Cell \#15, 20 and 23

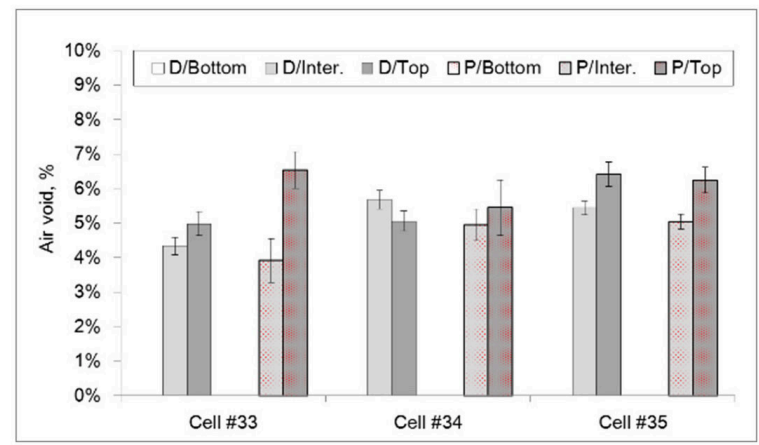

(a) Drive way vs. Pass way

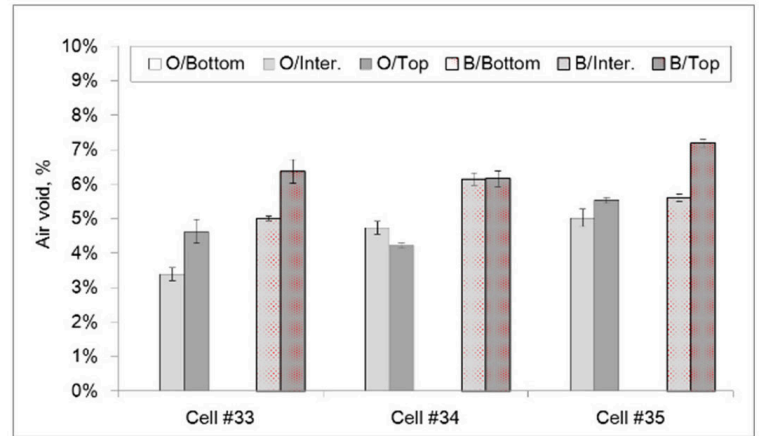

(b) On the wheel path vs. Between wheel path

Fig. 8 Air voids Comparisons among Cell \#33, 34 and 35

In Figures 6 and 8, the vertical line in the middle of each bar (i.e. $S(60 \mathrm{~s})$ or $m(60 \mathrm{~s}))$ represents the range of standard error, which can be expressed as:

$$
S E=\frac{\sigma}{\sqrt{n}}
$$

Where: $S E$ : standard error of air voids;

$$
\begin{gathered}
\sigma: \text { standard deviation of air voids; } \\
n: \text { the size of the sample }(n=4 \sim 6) .
\end{gathered}
$$

Based on the results shown in Tables 3 to 5 and Figure 6 to 8 , it was observed that the air voids in the bottom layer show higher values than those in the upper layer for Cells 2, 15, 34 and 78. In case of Cells 4, 20, 23, 33 and 35 an inverse trend was found. Among acid modified HMA mixtures (i.e. Cells 33, 34 and 35) only Cell 34 showed opposite of air voids distribution (higher air voids in the lower layer) in comparison with the other two Cells: Cells 33 and 35. In case of WMA mixtures (i.e. Cells 15 and 23) similar air voids content was observed between intermediate and top layer however, for RAP mixtures (i.e. Cell 20) remarkable differences of air voids between the top and the bottom part of the specimen were found.

\subsection{Statistical Comparison}

In order to numerically and quantitatively address the differences in air voids among the different test Cells built in $\mathrm{MN} / \mathrm{Road}$, a simple statistical test method (i.e. $t$-test) with 5\% significance (i.e.significant level $\alpha=0.05,5 \%$ error level) was used. Two statistical assumptions were set for this type of test:

1. Each observation follows the normal distribution.

2. Each observation has the same (and/or similar) standard deviation.

The test hypotheses were set as follows:

Null hypothesis

$$
: H_{0}: \mu_{\text {GroupA, air voids }}=\mu_{\text {GroupB, air voids }}
$$

Alternative hypothesis

$$
: H_{a}: \mu_{\text {GroupA, air voids }} \neq \mu_{\text {GroupB, air voids }}
$$

Where the mean (response) is $\mu=$ mean of air voids from each test group

The pooled standard deviation, $B_{P}$, can be computed as follows for air void comparison:

$$
B_{P, \text { air voids }}=\sqrt{\frac{\left(n_{\text {group } A}-1\right) \cdot B_{\text {GroupA, air voids }}^{2}+\left(n_{\text {group } A}-1\right) \cdot B_{\text {Group } B \text {,air voids }}^{2}}{n_{\text {GroupA }}-n_{\text {Group } B}-2}}
$$

Where:

$B_{\text {GroupA,air voids }}$ : standard deviation of air voids from Group A,

$B_{\text {GroupB, air voids }}$ : standard deviation of air voids from Group B,

$n_{\text {GroupA }}$ : number of specimens in Group A $(n=8 \sim 16)$,

$n_{\text {GroupB }}$ : number of specimens in Group B $(n=8 \sim 16)$, 
Using Equation (7), $t$-statistic can be computed as:

$$
t_{\text {air voids }}=\frac{\mu_{\text {GroupA, airv oids }}-\mu_{\text {GroupB, air voids }}}{B_{P, \text { air voids }} \cdot \sqrt{\frac{1}{n_{\text {groupA }}}+\frac{1}{n_{\text {group } B}}}}
$$

The degrees of freedom in this test hypothesis are calculated as follows:

$$
d f=\left(n_{\text {groupA }}+n_{\text {group } B}\right)-2
$$

Finally, $p$-value,the output of the $t$-test which provides the significance of the tested hypothesis, was calculated from Equations (8) and (9). In this research, three types of comparisons were considered as:

- Comparison 1: air voids comparisons between drive way (DW) and pass way (PW) location

- Comparison 2: air voids comparisons between On the wheel path (OWP) and Between the wheel path (BWP)

- Comparison 3: air voids comparisons among different layers (bottom (B), intermediate (I) and top (T))

All the computed results of $p$-value for air voids are presented in Tables 6 to 11 . When the $p$-value is less than $0.05(=5 \%)$, it indicates a significant difference in air voids content between two compared groups; for $p$-value $>0.05$, the two tested groups are statistically equivalent.

Table 6. Statistical Comparison Results for Cell 2, 4, 78

\begin{tabular}{|c|c|c|c|c|c|}
\hline \multirow{2}{*}{\multicolumn{2}{|c|}{ Contents }} & \multicolumn{2}{|c|}{ Comparison 1} & \multicolumn{2}{|c|}{ Comparison 2} \\
\hline & & $\mathrm{DW}(\mathrm{l})$ & $P W(O)$ & OWP & BWP \\
\hline \multirow{4}{*}{ Cell 2} & Average [\%] & 6.03 & 6.03 & 5.63 & 6.43 \\
\hline & C.V. [\%] & 17.06 & 22.66 & 23.19 & 15.02 \\
\hline & $t$-score & \multicolumn{2}{|c|}{0.999} & \multicolumn{2}{|c|}{0.065} \\
\hline & Significance & \multicolumn{2}{|c|}{ Non-significant } & \multicolumn{2}{|c|}{ Non-significant } \\
\hline \multirow{4}{*}{ Cell 4} & Average [\%] & 5.59 & 5.20 & 5.25 & 5.54 \\
\hline & C.V. [\%] & 19.09 & 23.24 & 17.22 & 24.36 \\
\hline & $t$-score & \multicolumn{2}{|c|}{0.405} & \multicolumn{2}{|c|}{0.546} \\
\hline & Significance & \multicolumn{2}{|c|}{ Non-significant } & \multicolumn{2}{|c|}{ Non-significant } \\
\hline \multirow{4}{*}{ Cell 78} & Average [\%] & 4.99 & 7.66 & 5.20 & 6.56 \\
\hline & C.V. [\%] & 20.22 & 14.29 & 24.62 & 26.18 \\
\hline & t-score & \multicolumn{2}{|c|}{0.000} & \multicolumn{2}{|c|}{0.037} \\
\hline & Significance & \multicolumn{2}{|c|}{ Significant } & \multicolumn{2}{|c|}{ Significant } \\
\hline
\end{tabular}
(Comparison Type 1 and 2)

DW (I): Drive way (Inside lane: Cell 78 only), PW (O): Pass way (Outside lane: Cell 78 only), OWP: On the wheel path, BWP: Between the wheel path
Table 7. Statistical Comparison Results for Cell 15, 20, 23

\begin{tabular}{|c|c|c|c|c|c|}
\hline \multirow{2}{*}{\multicolumn{2}{|c|}{ Contents }} & \multicolumn{2}{|c|}{ Comparison 1} & \multicolumn{2}{|c|}{ Comparison 2} \\
\hline & & DW & PW & OWP & BWP \\
\hline \multirow{4}{*}{ Cell 15} & Average [\%] & 6.40 & 6.76 & 5.81 & 7.35 \\
\hline & C.V. [\%] & 27.79 & 10.93 & 20.60 & 13.53 \\
\hline & $t$-score & \multicolumn{2}{|c|}{0.610} & \multicolumn{2}{|c|}{0.013} \\
\hline & Significance & \multicolumn{2}{|c|}{ Non-significant } & \multicolumn{2}{|c|}{ Significant } \\
\hline \multirow{4}{*}{ Cell 20} & Average [\%] & 5.98 & 5.49 & 5.68 & 5.80 \\
\hline & C.V. [\%] & 12.75 & 19.97 & 14.54 & 19.06 \\
\hline & $t$-score & \multicolumn{2}{|c|}{0.079} & \multicolumn{2}{|c|}{0.666} \\
\hline & Significance & \multicolumn{2}{|c|}{ Non-significant } & \multicolumn{2}{|c|}{ Non-significant } \\
\hline \multirow{4}{*}{ Core 23} & Average [\%] & 6.12 & 5.71 & 5.96 & 5.88 \\
\hline & C.V. [\%] & 19.77 & 31.83 & 24.04 & 28.51 \\
\hline & $t$-score & \multicolumn{2}{|c|}{0.526} & \multicolumn{2}{|c|}{0.895} \\
\hline & Significance & \multicolumn{2}{|c|}{ Non-significant } & \multicolumn{2}{|c|}{ Non-significant } \\
\hline
\end{tabular}
(Comparison Type 1 and 2)

Table 8. Statistical Comparison Results for Cell 33, 34, 35

\begin{tabular}{|c|c|c|c|c|c|}
\hline \multirow{2}{*}{\multicolumn{2}{|c|}{ Contents }} & \multicolumn{2}{|c|}{ Comparison 1} & \multicolumn{2}{|c|}{ Comparison 2} \\
\hline & & DW & PW & OWP & BWP \\
\hline \multirow{4}{*}{ Cell 33} & Average [\%] & 4.66 & 5.23 & 4.01 & 5.69 \\
\hline & C.V. [\%] & 19.12 & 33.89 & 22.88 & 16.17 \\
\hline & $t$-score & \multicolumn{2}{|c|}{0.415} & \multicolumn{2}{|c|}{0.000} \\
\hline & Significance & \multicolumn{2}{|c|}{ Non-significant } & \multicolumn{2}{|c|}{ Significant } \\
\hline \multirow{4}{*}{ Cell 34} & Average [\%] & \begin{tabular}{|l|l}
5.37 \\
\end{tabular} & 5.20 & \begin{tabular}{l|l}
4.47 \\
\end{tabular} & 6.15 \\
\hline & C.V. [\%] & 15.50 & 23.87 & 9.68 & 7.55 \\
\hline & $t$-score & \multicolumn{2}{|c|}{0.734} & \multicolumn{2}{|c|}{0.000} \\
\hline & Significance & \multicolumn{2}{|c|}{ Non-significant } & \multicolumn{2}{|c|}{ Significant } \\
\hline \multirow{4}{*}{ Core 35} & Average [\%] & 5.93 & 5.64 & 5.27 & 6.39 \\
\hline & C.V. [\%] & 15.75 & 15.21 & 9.73 & 13.57 \\
\hline & t-score & \multicolumn{2}{|c|}{0.458} & \multicolumn{2}{|c|}{0.001} \\
\hline & Significance & \multicolumn{2}{|c|}{ Non-significant } & \multicolumn{2}{|c|}{ Significant } \\
\hline
\end{tabular}
(Comparison Type 1 and 2)

Table 9. Statistical Comparison Results for Cell 2, 4, 78

\begin{tabular}{|c|c|c|c|c|}
\hline \multirow{2}{*}{\multicolumn{2}{|c|}{ Contents }} & \multicolumn{3}{|c|}{ Comparison 3} \\
\hline & & \multirow{2}{*}{$\frac{\text { Bottom }}{6.94}$} & \multirow{2}{*}{$\frac{\text { Intermediate }}{5.23}$} & \multirow{2}{*}{$\begin{array}{c}\text { Top } \\
-\end{array}$} \\
\hline \multirow{6}{*}{ Cell 2} & Average [\%] & & & \\
\hline & C.V. [\%] & 10.35 & 18.03 & - \\
\hline & t-score ${ }^{1}$ & 0.000 & - & - \\
\hline & $t$-score ${ }^{2}$ & - & - & - \\
\hline & $t$-score ${ }^{3}$ & - & - & - \\
\hline & Significance & Significant & - & - \\
\hline \multirow{6}{*}{ Cell 4} & Average [\%] & 4.16 & 5.57 & 6.45 \\
\hline & C.V. [\%] & 5.44 & 15.22 & 9.77 \\
\hline & t-score ${ }^{1}$ & 0.000 & No test & - \\
\hline & $t$-score ${ }^{2}$ & - & - & - \\
\hline & $t$-score ${ }^{3}$ & - & - & 0.000 \\
\hline & Significance & Significant & Significant & Significan \\
\hline
\end{tabular}
(Comparison Type 3) 


\begin{tabular}{|c|c|c|c|c|}
\hline \multirow{6}{*}{ Cell 78} & Average [\%] & - & 6.48 & 5.27 \\
\hline & C.V. [\%] & - & 23.97 & 23.91 \\
\hline & $t$-score ${ }^{1}$ & - & - & - \\
\hline & $t$-score ${ }^{2}$ & - & 0.068 & - \\
\hline & $t$-score ${ }^{3}$ & - & - & - \\
\hline & Significance & - & Non-Significant & - \\
\hline
\end{tabular}

$t$-score' : Airvoids between Bottom (B) and Intermediate (I) layer

$t$-score ${ }^{2}$ : Airvoids between Intermediate (I) and Top (T) layer

$t$-score ${ }^{3}$ : Airvoids between Bottom (B) and Top (T) layer

Table 10. Statistical Comparison Results for Cell 15, 20, 23 (Comparison Type 3)

\begin{tabular}{|c|c|c|c|c|}
\hline \multirow{2}{*}{\multicolumn{2}{|c|}{ Contents }} & \multicolumn{3}{|c|}{ Comparison 3} \\
\hline & & \multirow{2}{*}{$\begin{array}{c}\text { Bottom } \\
6.89\end{array}$} & \multirow{2}{*}{$\begin{array}{c}\text { Intermediate } \\
6.27\end{array}$} & \multirow[t]{2}{*}{ Top } \\
\hline \multirow{6}{*}{ Cell 15} & Average [\%] & & & \\
\hline & C.V. [\%] & 11.29 & 27.43 & \\
\hline & $t$-score $^{1}$ & 0.377 & - & - \\
\hline & $t$-score ${ }^{2}$ & - & - & - \\
\hline & $t$-score ${ }^{3}$ & - & - & - \\
\hline & Significance & Non-Significant & - & - \\
\hline \multirow{6}{*}{ Cell 20} & Average [\%] & 4.94 & 5.64 & 6.63 \\
\hline & C.V. [\%] & 13.10 & 14.63 & 8.12 \\
\hline & $t$-score ${ }^{1}$ & 0.011 & - & - \\
\hline & $t$-score ${ }^{2}$ & - & 0.000 & - \\
\hline & $t$-score ${ }^{3}$ & - & - & 0.000 \\
\hline & Significance & Significant & Significant & Significant \\
\hline \multirow{6}{*}{ Cell 23} & Average [\%] & 4.19 & 6.96 & 6.61 \\
\hline & C.V. [\%] & 21.20 & 8.88 & 17.07 \\
\hline & t-score ${ }^{1}$ & 0.000 & - & - \\
\hline & $t$-score ${ }^{2}$ & - & 0.449 & - \\
\hline & $t$-score ${ }^{3}$ & - & - & 0.000 \\
\hline & Significance & Significant & Non-Significant & Significant \\
\hline
\end{tabular}

Table 11. Statistical Comparison Results for Cell 33, 34, 35 (Comparison Type 3)

\begin{tabular}{|c|c|c|c|c|}
\hline \multirow{2}{*}{\multicolumn{2}{|c|}{ Contents }} & \multicolumn{3}{|c|}{ Comparison 3} \\
\hline & & \multirow{2}{*}{$\begin{array}{c}\text { Bottom } \\
-\end{array}$} & \multirow{2}{*}{$\begin{array}{c}\text { Intermediate } \\
4.19\end{array}$} & \multirow{2}{*}{$\begin{array}{l}\text { Top } \\
5.50\end{array}$} \\
\hline \multirow{6}{*}{ Cell 33} & Average [\%] & & & \\
\hline & C.V. [\%] & - & 21.59 & 22.12 \\
\hline & $t$-score $^{1}$ & - & - & - \\
\hline & $t$-score ${ }^{2}$ & - & 0.006 & - \\
\hline & $t$-score ${ }^{3}$ & - & - & - \\
\hline & Significance & - & Significant & - \\
\hline \multirow{6}{*}{ Cell 34} & Average [\%] & - & 5.44 & 5.19 \\
\hline & C.V. [\%] & - & 15.65 & 20.94 \\
\hline & $t$-score ${ }^{1}$ & - & - & - \\
\hline & $t$-score ${ }^{2}$ & - & 0.537 & - \\
\hline & $t$-score ${ }^{3}$ & - & - & - \\
\hline & Significance & - & Non-significant & - \\
\hline \multirow{6}{*}{ Cell 35} & Average [\%] & - & 5.31 & 6.36 \\
\hline & C.V. [\%] & - & 10.13 & 14.12 \\
\hline & $t$-score $^{1}$ & - & - & - \\
\hline & $t$-score ${ }^{2}$ & - & 0.002 & - \\
\hline & $t$-score ${ }^{3}$ & - & - & - \\
\hline & Significance & - & Significant & - \\
\hline
\end{tabular}

The statistical analysis shows that except for Cell 78 (PG 58-34, 12.5mm dense mix with Elvaloy and PPA modification) there are no significant differences in air voids distributions between drive way (DW) and pass way (PW) (see results of Comparison 1 in Tables 6, 7 and 8). Based on this results, the use of WMA mixtures in combination with taconite aggregates is recommended for pavement constructions, since similar air voids trends were observed in Cell 23 (PG 58-34, WMA+taconite aggregate) in comparison with the conventional HMA pavement mixtures, Cells, 2 and 4, prepared with more expensive asphalt binder (PG 64-34). This trend was also observed in the RAP mixtures (Cell 20).

Significant statistical differences were found when comparing air voids on the wheel path (OWP) and between wheel path (BWP) locations (Cells 15, 33, 34, 35 and 78) with the exception of Cells 2, 4, 20 and 23 (see results of Comparison 2 in Tables 6, 7 and 8). This means no significant variations in air voids were observed in conventional HMA mixtures, RAP mixtures and WMA mixtures combined with taconite aggregates which also supports the use of RAP and WMA (w/ taconite aggregate) technology in asphalt pavement industry. In all asphalt mixture cores, higher amount of air voids were observed in BWP locations compared to OWP locations due to traffic load.

Finally, all cells showed significant variations in air voids moving from the top trough the intermediate layer down to the bottom, except Cells 15, 34, and 78 (see results of Comparison 3 in Tables 10, 11 and 12). For Cells 2, higher amount of air voids were observed in the lower layer however, opposite results were found in Cell 4 even though both core contains same mix design but different type of surface layer material.

Generally, better performance (i.e. resistance) for rutting and low temperature cracking can be expected in the pavement layer when no significant differences of air voids are observed between OWP and BWP locations. Therefore, based on the results shown in Tables 6 to 12, using WMA, taconite aggregates and RAP is a valuable construction option and has the potential of becoming a construction practice for asphalt paving technologists since similar air void distributions can be expected using less expensive binder (e.g. PG 58-34) compared to the conventional HMA mixtures 
(e.g. PG 64-34). Nevertheless, amount and quality control when using recycled materials and new technologies (e.g. WMA) into asphalt mixtures should be considered since these may affects low temperatures properties. For example higher stiffness and limited relaxation capabilities can be observed when adding Taconite and/or RAP into asphalt mixtures, even though rutting resistance at high temperatures is improved (Moon et al., 2013).

\subsection{Multiple Comparison}

In Tables 8 and 11, similar results from the air voids comparisons were observed among acid modified HMA mixtures (Cells 33, 34, 35). Recently the polymer modifier PPA was introduced in HMA industries because of its cheaper price compared to the conventional modifiers such as SBS (Zegeye et al., 2012). However, due to the poor performance at low temperatures, PPA is still not widely used even though it was found that PPA+SBS mixtures show similar mechanical properties at low temperature compared to SBS asphalt mixtures (Zegeye et al., 2012). Therefore, to further investigate and compare the air void results among Cells 33, 34 and 35, multiple comparisons were performed with two methods: Fisher's Least Significant Difference (LSD) and Tukey's Studentized Range Test method (SRT) (Cook and Weisberg, 1999).

According to LSD method, the value of $t$-static can evaluate the differences between groups $a$ and $b$ as:

$$
t=\frac{\mu_{a}-\mu_{b}}{\sqrt{s^{2} \cdot\left(\frac{1}{r_{a}}+\frac{1}{r_{b}}\right)}}
$$

Where: $\mu=$ mean, $s=$ the means quare error and $r$ $=$ sample size in certain group.

Equation (10) follows a student's $t$-distribution with $n-k$ ( $n=$ whole size of element, $k=$ size of compared groups) degrees of freedom. Finally, a difference between the means of Group $a$ and $b$ is statistically significant if the following condition is met(see Equation (11)).

$$
\left|\mu_{a}-\mu_{b}\right| \geq L S D=t_{a / 2 ; n-k} \cdot \sqrt{s^{2} \cdot\left(\frac{1}{r_{a}}+\frac{1}{r_{b}}\right)}
$$

The Tukey's SRT method uses the studentized parameter $Q$ :

$$
Q=\frac{\left(\mu_{\max }-\mu_{\min }\right)}{\sqrt{\frac{s^{2}}{r}}}
$$

Where $\mu_{\max }=$ the larger of the two means being compared, $\mu_{\min }=$ the smaller of the two means being compared.

Similarly to Equation (10), Equation (12) has $n-k$ degrees of freedom. Therefore, if means difference is higher than computed result of Equation (12), the two means are mentioned to be significantly different with level of $\alpha(=0.05)$. All the computed results are presented in Table 12.

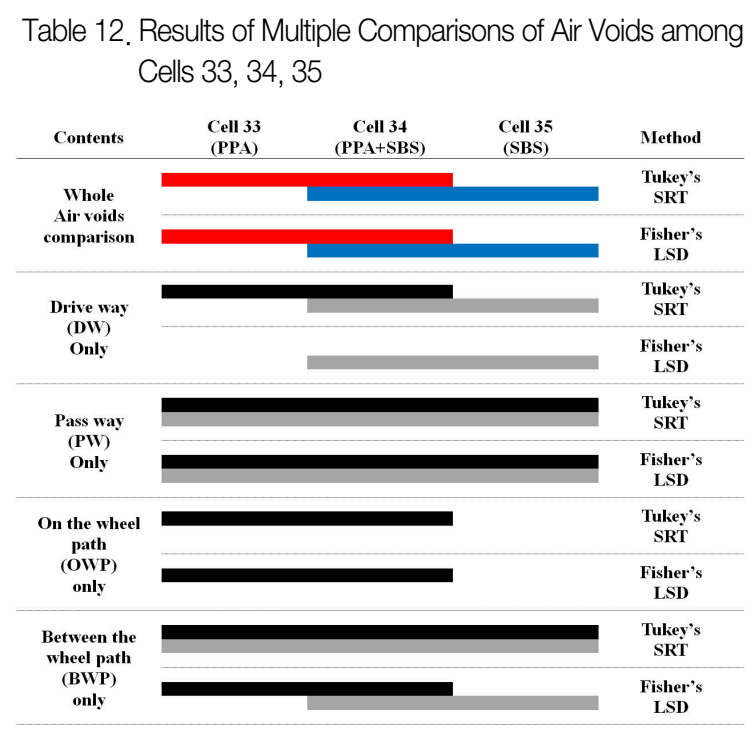

From the results in Table 12, no significant differences in air voids between Cells 33 vs. 34 and Cells 34 vs. 35 were observed. However, significant differences between Cells 33 and 35 were found. Usually the poly-modifier SBS is used to modify the properties of asphalt binder; however, some agencies and industries used PPA because of its lower cost with reasonable performances. In many studies it was found that PPA added mixtures showed similar properties at high temperatures; however poor performances at low temperature were found in comparison with the SBS added mixtures. Similar results were observed in this study where mixtures with PPA showed lower air voids compared to mixtures with SBS (see Table 8). Nevertheless, mixtures with PPA+SBS showed similar amounts of air voids compared to SBS 
mixtures, which means PPA can be used in asphalt mixtures in combinations with SBS. Note that in this study only limited numbers of asphal tmixtures were tested and the testing parameter was air voids only; therefore, additional experimental verification which includes more mixture types and addressing also different parameters is needed for improving the understanding of mixture performance.

\section{SUMMARY AND CONCLUSIONS}

Several mechanical and physical properties are related to performances of asphalt mixtures at high and low temperatures. One important material property in HMA, which is related to rutting and low temperature cracking, is the amount and distribution of air voids. In this study, values of air voids at different asphalt pavement testing cells built at the MN/Road facility, and prepared with different mix designs, were calculated and compared graphically and numerically. From the analyses performed, a number of conclusions can be drawn.

1. Higher air voids content was found in the lower positioned layers in comparison to higher positioned layers (e.g. bottom vs. intermediate, intermediate vs. top, bottom vs. top) for some mixtures (Cells 2, 15, 34, 78) however, opposite results were found from the rest of mixtures (Cells $4,20,23,33,35)$.

2. In case of WMA mixtures, significant differences in air voids between OWP and BWP locations were observed compared to conventional HMA mixtures which can lead rutting at high temperatures and cracking at low temperatures, respectively. However, when taconite is added in WMA mixtures, similar results in air void distribution were observed compared to conventional HMA mixtures, even though binder with lower and cheaper PG was used. This indicates that WMA mixture with combination of taconite can be used in real asphalt pavement construction providing reasonable performances in comparison with the conventional HMA mixtures.

3. In case of recycled mixtures, containing up to $30 \%$ RAP, no significant differences in air voids distributions were found in comparison with the conventional HMA mixtures. This highlights the cost and environmental benefits of using recyclable materials in conventional
HMA.

4. All the acid modified HMA mixtures showed significant differences in air voids content between OWP and BWP locations. This indicates that these mixtures are more prone to rutting and low temperature cracking compared to conventional HMA mixtures. After performing multiple comparisons, no significant difference in air voids was found between mixtures with PPA+SBS and SBS. However, significant differences were observed between mixtures with PPA and SBS. It can be assumed that the cheaper polymer modifier PPA can be used in combination with SBS for preparing HMA mixtures without reducing its mechanical properties.

In this paper, nine different types of asphalt mixture cores obtained from MN/Road testing cells were used for computation and comparison of air voids the properties related to rutting and low temperature cracking. Nevertheless, additional research is needed to investigate the air void distributions at different depths in the asphalt mixture layered structure. Different binder grades should be also included in a future study for expanding the finding of the present research. Moreover, additional research should be performed including other types of mechanical tests to verify the benefit of using WMA technology with taconite aggregate. Further research is needed for investigating the use of different binder grades. Therefore, other factors (e.g. complex modulus, creep stiffness, $m$-value and thermal stress) which affect high and low temperatures properties of asphalt binders and corresponding mixtures need to be evaluated. Hence, more experimental work and analysis are needed to compare the mechanical performances of WMA, RAP mixtures and acid modified HMA mixtures. This is part of ongoing studies and will be published in a forthcoming paper.

\section{ACKNOWLEDGEMENTS}

The authors would like gratefully acknowledge the Minnesota Department of Transportation. (MN/DOT) for providing the materials used in this study, and Mugurel Turos, the scientist of asphalt pavement lab at the University of Minnesota (U. of MN), for helping during the preparations of asphalt mixtures specimens.

\section{References}

AASHTO T 313-05, (2006), "Determining the Rheological Properties of Asphalt Binder Using a Dynamic Shear 
Rheometer (DSR)", American Association of State Highway and Transportation Officials (AASTO).

AASHTO T 313-06, (2006), "Determining the flexural creep stiffness of asphalt binder using the Bending Beam Rheometer (BBR)", American Association of State Highway and Transportation Officials (AASHTO).

AASHTO T 322-03, (2006), "Determining the creep compliance and strength of hot mix asphalt (HMA) using the Indirect Tensile (IDT) test device", American Association of State Highway and Transportation Officials (AASHTO).

AASHTO T 166-05, (2007), "Standard Method of Test for Bulk Specific Gravity of Compacted Hot-Mix Asphalt Using Saturated Surface-Dry Specimens", American Association of State Highway and Transportation Officials (AASHTO).

AASHTO T 342-11, (2011), "Standard Method of Test for Determining Dynamic Modulus of Hot-Mix Asphalt Concrete Mixtures", American Association of State Highway and Transportation Officials (AASHTO).

ASTM Designation: D7552-09, (2009), "Standard Test Method for Determining the Complex Shear Modulus, G*, of Bituminous Mixtures Using Dynamic Shear Rheometer", American Society for Testing and Materials international (ASTM).

Barksdale, R.D. and J.H. Miller II., (1977), "Developement of Equipment and Techniques for Evaluating Fatigue and Rutting Characteristics of Asphalt Concrete Mixes", School of Civil Engineering, Georgia Institute of Technology, SCEGIT-77-149.

Brown E. R. and Cross S. A., (1992), "A National Study of Rutting in Hot Mix Asphalt (HMA) Pavements", National Center for Asphalt Technology (NCAT) Report no. 92-5: 1-46.

Buncher M. S. and Rosenberg C., (2012), "Best Practices for Constructing and Specifying HMA Longitudinal Joints", Final report, Asphalt Institute.

Cook R. D. and Weisberg S., (1999), "Applied Regression Including Computing and Graphics", Wiley Series in Probability and
Statistics, U.S.

Harvey J. T. and Tsai B. W., (1996), "Effects of Asphalt Content and Air Void Content on Mix Fatigue and Stiffness", Transportation Research Record (TRR), 1543:38-45.

Marasteanu M., Velasquez R., Cannone Falchetto A., Zofka A., (2009), "Development of a simple test to determine the low temperature creep compliance of asphalt mixture", IDEA Program Final Report NCHRP 133, Transportation Research Board of the National Academies.

Masad E. and Somadevan N., (2002), "Microstructural FiniteElement analysis of influence of localized strain distribution on asphalt mix properties", Journal of Engineering Mechanics, 128(10):1105-1114.

Minnesota Department of Transportation (MN/DOT), (2013), "MN/ROAD Test Cells", Available from: http://www.dot. dtate.mn.us/mnroad/testsections. [21 August 2013]

Moon K.H., Cannone Falchetto A., Marasteanu O. M., (2014), "Using Recycled Asphalt Materials as An Alternative Material Source in Asphalt Pavements", Korean Society of Civil Engineering, 18(1),pp.149-159.

Oliver J. W. and Alderson A. J., (1995), "The effect of air void content on resilient modulus, dynamic creep and wheel tracking results", ARRB Transport Research no. 272.

Zelelew H. M., Papagiannakis A. T. and Masad E., (2008), "Application of Digital Image Processing Techniques for Asphalt Concrete Mixture Images", The 12th International Conference of International Association for Computer Methods and Advances in Geo-mechanics (IACMAG) Goa, India.

Zegeye T. E., Moon K. H., Turos M., Clyne T. R., Marasteanu O. M., (2012), "Low Temperature Fracture Properties of Polyphosphoric Acid Modified Asphalt Mixtures", American Society of Civil Engineering (ASCE), Journal of Material in Civil Engineering, 24(8):1089-1096. 